\title{
フィールドエミッションの最近の進展と 電子源としての期待
}

\author{
石 川 順 三 \\ 京都大学大学院工学研究科電子物性工学専攻 国606-8501 京都府京都市左京区吉田本町 \\ (2001 年 7 月 2 日受理)
}

\section{Current Status of Field Emission Researches and \\ Expectation for New Electron Sources}

\author{
Junzo ISHIKAWA \\ Department of Electronic Science and Engineering, Kyoto University \\ Yoshida-honmachi, Sakyo-ku, Kyoto 606-8501
}

(Received July 2, 2001)

\begin{abstract}
A new electron source which consists of microsize field emitter arrays attract strong attention for realizing new applications such as flat panel display, super-high frequency vacuum devices etc. Although the conventional field emitter that is usually a single crystal tungsten needle is operated under an ultra-high vacuum condition, new microsize field emitter arrays are required to be prepared by deposition methods and to be operated under a normal vacuum condition. Therefore, the researches on the new materials and structures for the development of microsize field emitter arrays have been needed. The selection of a low work function material as an emitter material is a prospective method to realize a stable operation of microsize field emitter array.
\end{abstract}

\section{1.はじめに}

フィールドエミッション (電界電子放出) は , 針状エ ミッタの先端から高密度のトンネル電流を引き出すこと により得られるため, 電子ビームは高輝度で光のエネル ギ一幅も狭い。光のため, 電子顕微鏡, 電子線描画装置, 電子ビームを用いた分析器などの理想的な電子発生法と して利用されてきた。しかし, 最近, 微小なエミッタア レイからのフィールドエミッションを用いる新しい電子 源が開発され, フィールドエミッションの応用領域が一 気に拡大しようとしている。

この新たなフィールドエミッタアレイは, ナノメー タ〜ミクロンメータ寸法のマルチエミッタ電極を, 半導 体の微細加工に用いられている露光, 蒸着, エッチング 技術やマイクロマシーニング技術を駆使して形成する。

E-mail: ishikawa@kuee.kyoto-u.ac.jp
安定に動作する微小なフィールドェミッタアレイを用い た電子源ができれば, 半導体素子の動作速度を遙かに超 える超々高速デバイス，低消費電力・高輝度・高視野角 が実現できるフィールドェミッション型フラットパネル ディスプレイ (FED), 高速でナノメータ精度の露光が 可能な超高速電子ビーム描画装置など，次世代技術やデ バイスにおいて数多くのブレークスルーが期待できる。

本報告では, まず, 現在開発されつつある種々の微小 フィールドエミッタアレイを用いた微小電子源の構造と 性能を概要する。次に, 微小フィールドエミッタアレイ は従来のフィールドエミッタとどのような点で異なるか について述べ, 最後に关れらの問題点と対処法について 概説する。

2 . 開発されつつある種々の微小フィールドェ ミツタ

微小フィールドエミッタを構造で分類すると，基板に 
対してエミッタ，ゲート，アノード電極が垂直方向に並 ぶ縦型と, 横方向に並ぶ横型がある。また, 不定形にエ ミッタが並ぶものとしてカーボンナノチューブがある。 エミッタ材料としては金属, 半導体, 炭素系材料など種々 のものが用いられる。

\section{1 縦型構造}

縦型の典型は, Fig. 1 に示すスピント型である。SRI のSpindt が独特の製作法を用いて開発したもので, フ イールドエミッタ型微小電子源の原型である ${ }^{1)}$ 。現在試 作されているフィールドエミッション型フラットパネル ディスプレイの電子源として最も多くのものに利用され ている。エミッタに用いる金属はモリブデンが一般的で あるが, 他の金属が利用されることもある。真空状態や エミッタ材料などが十分に良好な管理下で作製されたエ ミッタアレイでは, 約 $100 \mathrm{~A} / \mathrm{cm}^{2}$ の高電流密度で, ほぼ $100 \%$ の高動作率のものが得られる。

シリコン基板材料は, LSI (大規模半導体集積回路) 作製において微細加工法が完成した材料である。したが って，今まで培ってきた Si 微細加工法 (エッチング) を用いてエミッタを形成する方法が多くの研究者によっ て行われてきた。Fig. 2 は, シリコンを材料としたフィ 一ルドエミッタの構造を示す。ただし, 半導体からの電 界電子放出については, 未だに十分な理解が得られてい るとは言えず, 光の動作の理解には引き続き研究が必要

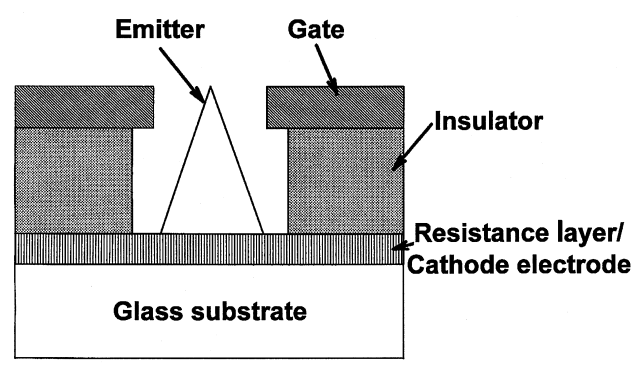

Fig. 1 Spindt type microsize field emitter.

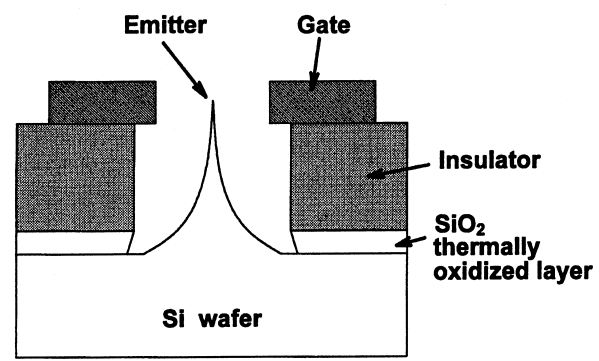

Fig. 2 Silicon microsize field emitter.
である。しかし後述するように，半導体本来の性質を利 用することにより, 動作の安定化を図ることができる特 長がある。

どのような材料でも正確な形状のエミッタにできる方 法として, モールド法がある。予め, シリコン基板など にエミッタの型 (モールド) をエッチング技術によって 作製し，光の型の中に好みのエミッタ材料を埋め込み(蒸 着)，光の後シリコン基板を溶かし去ると，Fig. 3 に示 すようなエミッタができる。形状の光ろったエミッタを 形成できる特長がある。

\section{2 横型構造}

Fig. 4 に示すような横型の素子は, すべての電極が平 面構造なので, MOS あるいは MIS FET 素子の作製法を そのまま適用できる。陰極 (エミッタ電極) のエッジ部 分から電子放出させる構造である。しかし, 平面電極構 造では電子の軌道制御が難しく，電子ビームもかなり拡 がるので, 特殊用途に限って用いられる。

\section{3 不定形型}

前述した縦型および横型は, 種々の材料を電界放出に 適した形状に意図的に加工する方法であるが , 材料产の ものが電界放出に適したナノメータ径の細い系状の形状 を持つカーボンナノチューブを電界放出に利用する方法 がある。

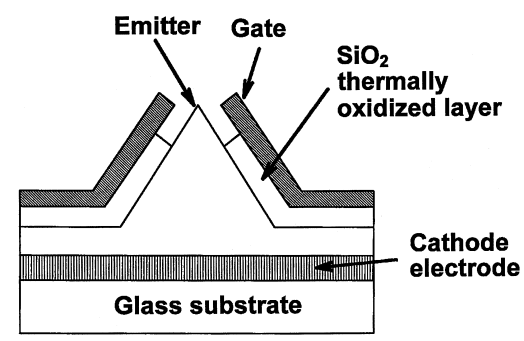

Fig. 3 Microsize field emitter fabricated by the mold method.

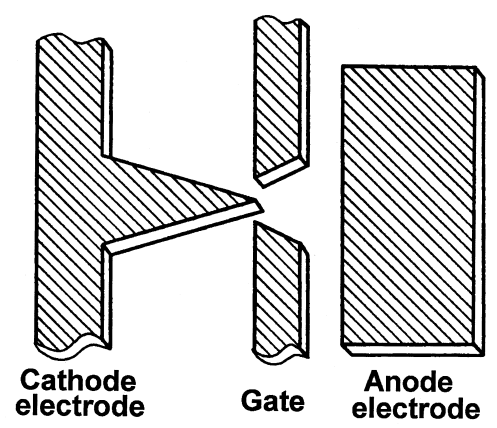

Fig. 4 Lateral structure type microsize field emitter. 


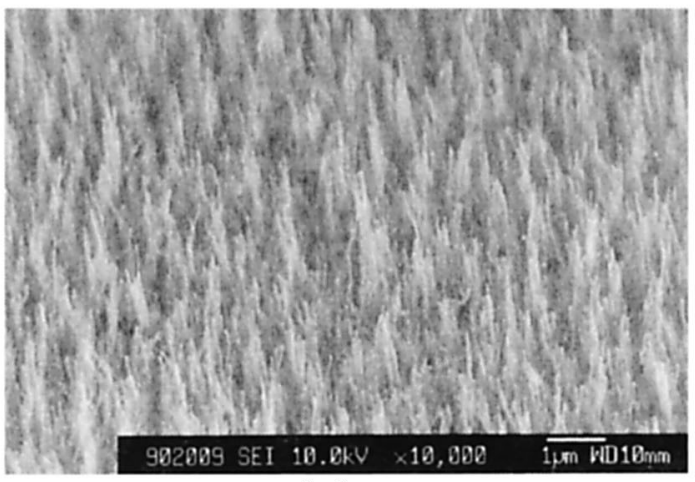

(a)

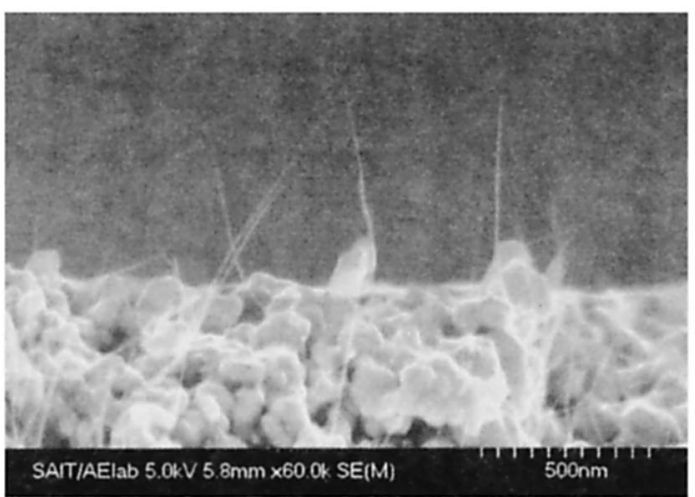

(b)

Fig. 5 (a) Frog type carbon nanotube emitter and (b) printed carbon nanotube emitter.

現在 , Fig. 5 (a) に示すようにカーボンナノチューブ を剣山のように成長させて電界放出させようとする試 み² や，Fig. 5 (b) に示すようにカーボンナノチューブ を印刷技術で塗布しエミッタを形成しようとする方法” が, 多くの研究機関で研究されている。

3 . 微小フィールドエミッタを用いた電子源の 電流密度性能と応用

\section{1 電流密度}

Fig. 6 は, 米国で開発中のクライストロード (Klystrode) (電界放出の非線形性を使って電子ビームを 集群させてマイクロ波増幅や発振を行う超高周波電子 管) のために開発された微小フィールドエミッタアレイ の写真を示す4)。クライストロードには非常に高い電流 密度の電子ビームが要求されることに対応して, パッキ ング密度の高い微小電子源が開発されている。特にMIT で開発された微小フィールドェミッタアレイは, $1 \mu \mathrm{m}$

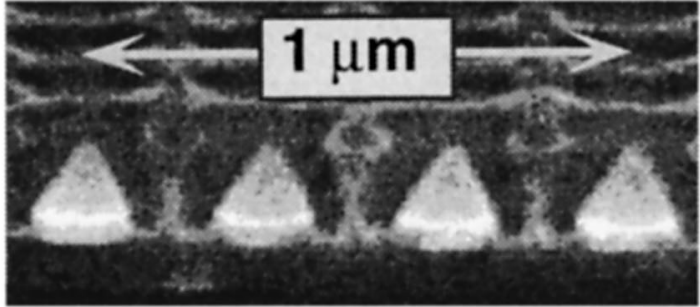

(a)

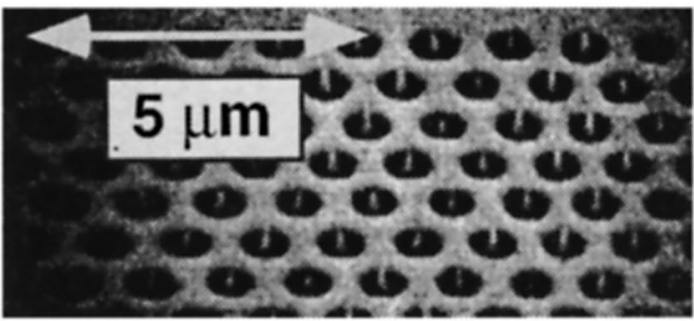

(b)

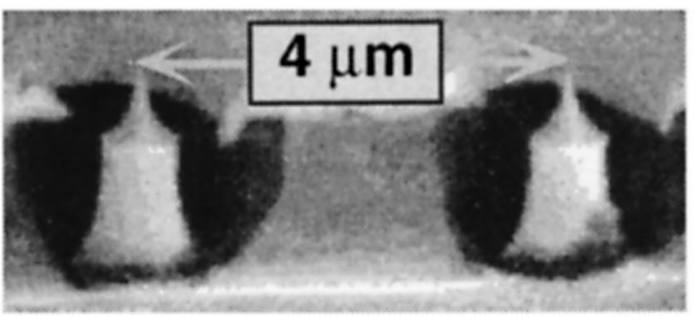

(c)

Fig. 6 Refractory metal microsize field emitter arrays developed by (a) MIT and (b) SRI, and (c) silicon microsize field emitter array for Klystrode.

の間に 3 個のエミッタが入るほど密度が高く, 6000 個 $(25 \mu \mathrm{m} \times 25 \mu \mathrm{m})$ のエミッタで, 兴の電流密度はパルス 動作ではあるが $2400 \mathrm{~A} / \mathrm{cm}^{2}$ と極めて高い值を実現して いる。

高電流密度の微小フィールドエミッタアレイとして， 日本では小沼らが， Fig. 7 に示すような CRT のための マルチェミッタ微小電子源を開発している5)。50 $\mu \mathrm{m}$ 直 径の中に , 868 個のエミッタアレイがあり，連続動作で， $50 \mathrm{~A} / \mathrm{cm}^{2}$ の電流密度が得られる。

このように, 微小フィールドェミッタアレイの最大動 作電流密度は, 熱電子放出型陰極の最大動作電流密度よ り $2 \sim 3$ 桁高い電流密度での動作が可能であることが実 証されている。 


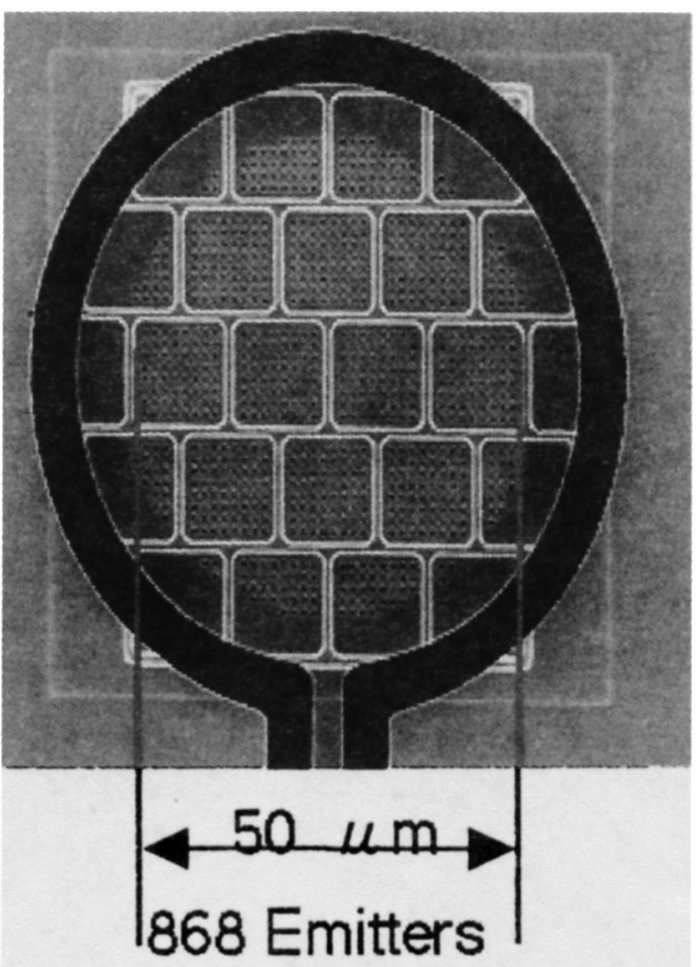

Fig. 7 Microsize field emitter array for cathode ray tubes developed by NEC.

\section{2 応用人の展開}

\section{2.1 フラットパネルディスプレイ}

微小フィールドエミッタアレイを使用したフラットパ ネルディスプレイは一般に FED と呼ばれ, 微小フィー ルドェミッタアレイを利用した応用の中で最も早く実用 化が実現するであろうと言われている。高輝度, 高視野 角などブラウン管のもつ長所を光のまま活かして, 低消 費電力で平面状の表示が可能となる。

Fig. 8 に示すように , 数百個の微小フィールドエミッ タから放出された電子ビームを, エミッタから数百 $\mu \mathrm{m}$ 離した位置にある RGB 弚れ光れの蛍光体に照射し, 発 光させる。Fig. 8 のものでは電子の最終加速電圧が数百 $\mathrm{V}$ の低電圧型であるが, エミッタと蛍光体との間隙を数 $\mathrm{mm}$ とし数 $\mathrm{kV}$ の電圧を印加する高電圧型も開発されて いる。

\section{2.2 超高周波デバイス}

前述したクライストロードは, フィールドエミッショ ンの電流電圧特性が非線形であることを積極的に利用す る。引き出し電界に増幅しようとする高周波信号を重畳 して引き出された電子ビームが高周波に応じて集群する 性質を使う。理論的には数十\%の高周波への変換効率が

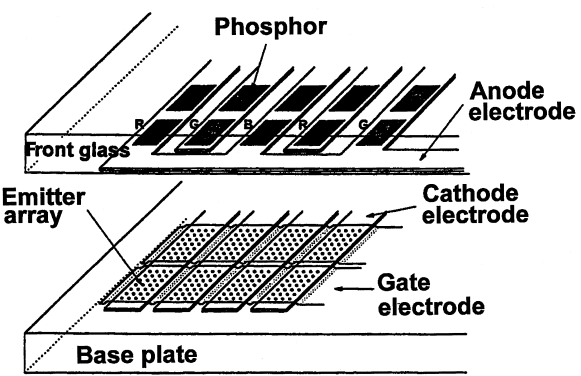

Fig. 8 Illustration of full color and low voltage field emitter display.

予測されているが , 試作されたものでは効率が $1 \%$ 以 下である。

微小フィールドエミッタアレイが高電流密度でヒータ 不要の電子源である特長を活かして, 微小フィールドエ ミッタアレイから引き出された電子ビームを, 光のまま 従来の進行波管に使用する応用も行われている。ヒータ 電力が不要になるため, 全体の電力効率が改善される。

3.2 .3 微小フィールドエミッタアレイを用いた電子 ビーム露光

従来より $2 \sim 3$ 桁高い処理速度をもつ電子ビーム露光 が実現できる可能性がある。電子ビーム露光用の超高輝 度電子源としての性能は, 電流密度に加えてエネルギー 幅や電流変動が小さい必要がある。フィールドェミッシ ヨン電子のエネルギー幅は潜在的には熱電子放出より小 さい。したがって, 電流変動の極めて少ないフィールド エミッタアレイの開発が , この応用を実現に導くための 課題である。

4. 従来のフィールドエミッタと新たな微小フ イールドエミッタアレイの違い

従来から利用されているフィールドエミッタと新たな 微小フィールドェミッタ (アレイ) の材質および動作雰 囲気の違いを，Table 1 に示す。

電子顕微鏡などに使用されてきている従来のフィール ドェミッタは，一本だけの単独針で利用する。炎のため， 電界放出に適した理想的な材質や結晶状態のエミッタで 作製することができる。良く用いられるエミッタは，先 端の曲率半径を $0.1 \mu \mathrm{m}$ 程度としたタングステン単結晶 針あるいは光の表面に $\mathrm{Zr}-\mathrm{O}$ 単原子層を付けたものであ る。タングステンを用いるのは強電界やジュール熱に耐 えイオン衝撃にも強いためである。また単結晶を使用す るのは, 安定な電子放出が期待できる特定の結晶面を利 用するためである。このようなエミッタにおいては,Fig. 9 (a) に示すように, 数 $\mathrm{mm}$ 離れた位置に引き出し電極 
Table 1 The difference in material and operating vacuum condition between conventional field emitter and microsize field emitter array.

\begin{tabular}{lll}
\hline & $\begin{array}{c}\text { Conventional } \\
\text { field emitter }\end{array}$ & \multicolumn{1}{c}{$\begin{array}{c}\text { Microsize } \\
\text { emitter array }\end{array}$} \\
\hline $\begin{array}{l}\text { Material } \\
\text { (Crystallinity) }\end{array}$ & $\begin{array}{l}\text { Tungsten } \\
\text { (single crystal) }\end{array}$ & $\begin{array}{l}\text { Deposition film } \\
\text { (amorphous) } \\
\text { Si (single crystal) } \\
\text { Carbon nanotube }\end{array}$ \\
$\begin{array}{ll}\text { Operating } \\
\text { vacuum } \\
\text { condition }\end{array}$ & Ultra-high & Normal \\
& vacuum & vacuum \\
$\left(10^{-8} \mathrm{~Pa}\right)$ & $\left(10^{-5} \sim 10^{-4} \mathrm{~Pa}\right)$ \\
\hline
\end{tabular}

を設置し数 $\mathrm{kV}$ の電圧を印加し電子を引き出す。エミッ 夕先端近傍の等電位面は球形状をしているが, 印加電圧 が高いため光の球面状内の電位は引き出された電子が残 留ガスを十分電離できるだけのエネルギーに加速され る。残留ガスがイオン化されると，イオンは電位分布が 球形状のため, 電子と同じ軌道を逆流してエミッタを衝 撃し光の先端を破壊する。このエミッタ先端の破壊を防 ぐためには, 真空度を $10^{-8} \mathrm{~Pa} よ り$ 良い状態で動作させ なければならない。

微小フィールドエミッタアレイでは, 数多くのミクロ ン寸法のエミッタ電極をアレイ状に形成しなければなら ないので，蒸着法によってエミッタを作製する方法が主 流である。蒸着法によって作製するエミッタは非晶質で あり, またかなり多くの欠陥を多く含んでいる。光のた め表面状態は理想的な単結晶とは著しく異なっている が, 弚のような表面から電子放出を行わなければならな い。

また, 微小フィールドエミッタの電極間距離は, Fig. 9 (b) に示すように, $\mu \mathrm{m}$ 程度のため, 電界放出に必要 な印加電圧は数十 V と非常に低い。このとき, エミッ 夕先端近傍の等電位面が球形状の領域は電位が数 V 以 内である。エミッタから放出された球形状内の電子はイ オン化に必要なエネルギーを持つことはないので残留ガ スと衝突してもイオンを生じない。すなわち, 電子軌道 を逆流するイオンは生じないので, この機構によるエミ ッタの破壊はない。このことから，微小フィールドェミ ッタアレイの動作真空度は上記の単独針に比べて数桁悪 い $10^{-5} \sim 10^{-4} \mathrm{~Pa}$ でも大丈夫である。

このように, 従来の単結晶針構造のエミッタと新たな 微小フィールドエミッタアレイでは, エミッタ材料およ び電極構成に大きな隔たりががあるため, 従来のエミッ 夕の研究成果を兴のまま転用できない。すなわち, 微小 フィールドェミッタアレイに適した材料の研究と, 新た な構造に対する研究が必要になってきた。

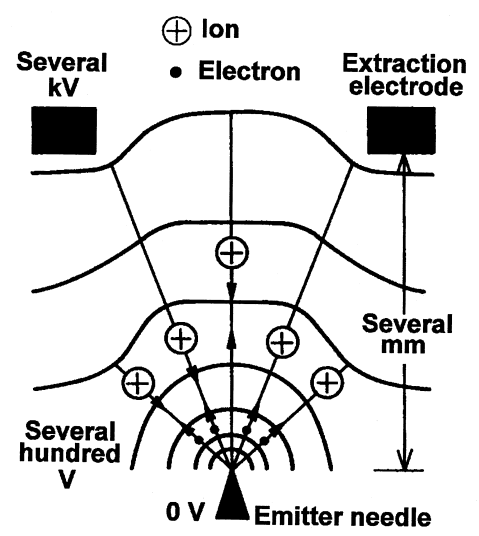

(a)

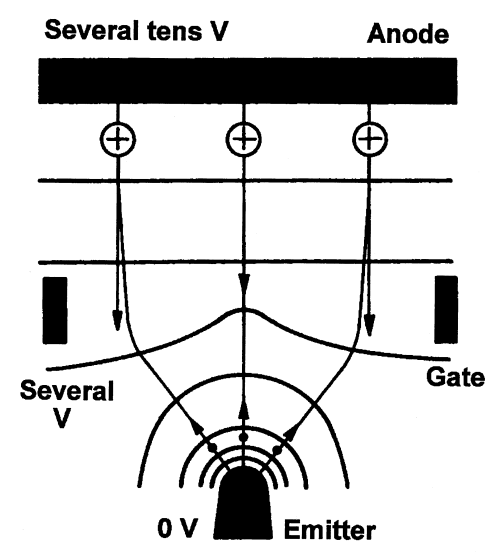

(b)

Fig. 9 Electric field distributions around an emitter tip head. (a) conventional field emitter and (b) microsize field emitter.

\section{5 . 微小フィールドエミッタアレイの問題点}

微小電子源の動作特性において最も問題となるのは, 兴の電流変動, すなわち, 安定性である。

Fig. 10 は微小フィールドェミッタからの放出電流の 時間経過の例を示したものである。電流にはフリッカ雑 音やステップ・スパイク状杂隹音が頻繁に観測される。こ の原因は, 動作真空度があまり良くないことによる残留 ガスやエミッタを高温で脱ガスできないために吸蔵ガス が放出し, エミッタ表面に吸着して表面の仕事関数が変 動したり，残留ガスの電離によってできたイオンが逆流 しイオン衝撃によって先端構造が変化して電流変動が起 こるためである。

したがって , 微小フィールドエミッタによる実用的な 


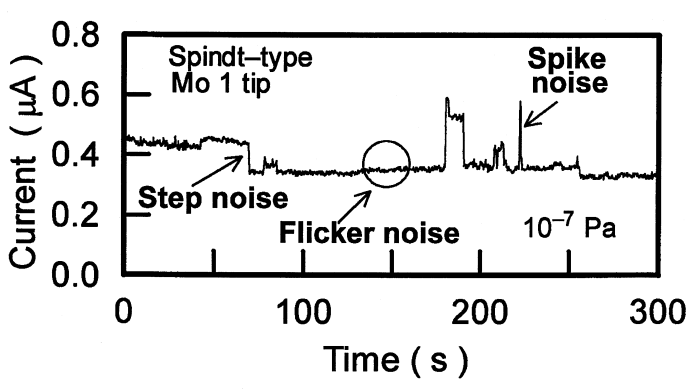

Fig. 10 Typical noise spectrum of a current extracted from a microsize field emitter.

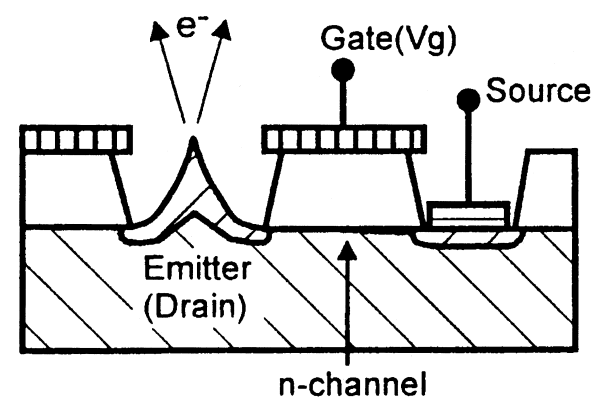

Fig. 11 Silicon microsize field emitter with MOSFET structure.

電子源を得るためには, 電流変動をできるだけ少なくす る工夫が必要である。

5.1 電子回路的な帰還回路による安定化

最も簡単な帰還方法は, 十分大きな抵抗を回路に直列 に入れることである。この方法は安価な方法であるため， スピント型の安定化によく用いられている。

$\mathrm{Si}$ エミッタの場合には, 半導体の特長を活かし , シ リコン基板に , Fig. 11 に示すようにMOSFET 構造を組 み込むことにより，制御性の高い負帰還回路を形成する ことができる゙)。トランジスタの増幅特性すなわち電流 制御特性が入るため, 電流の安定性は高い。しかし, 電 流変動の制御に伴いエミッタ先端の電位が変化するの で, 放出電子のエネルギーか変化する可能性がある。

5.2 エミッタ材料の選択 (高融点, 不活性材料)に よる安定化

エミッタ材料兴のものの選択により電流の安定化を图 ることも重要な手法である。この方法はより本質的な方 法なので, 複雑な構造を必要とせず安定化を図ることが でき, コスト面での低減にも役立つ。

エミッタ動作時にはエミッタの表面温度はかなり高く なっている。したがって , 表面原子のマグレーションは できるだけ少ないことか染隹音低減には重要である。これ

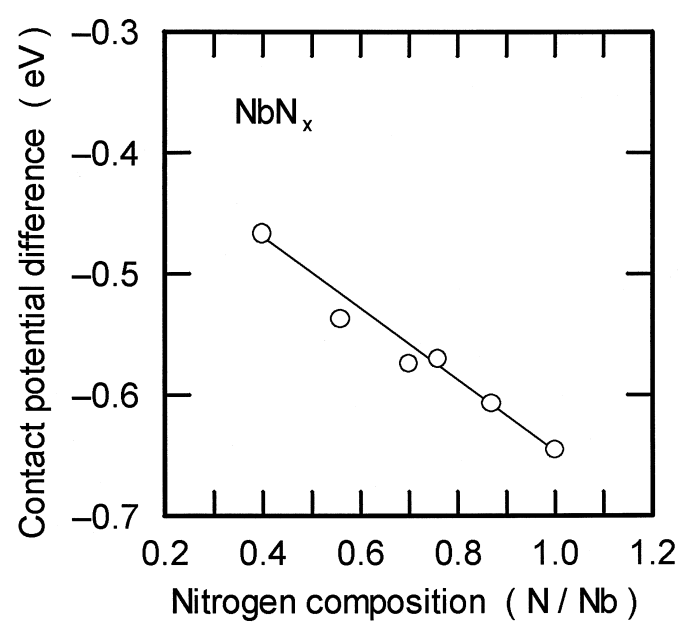

Fig. 12 Contact potential difference related to work function as a function of nitrogen composition of $\mathrm{NbN}$ film prepared by ion beam assisted deposition.

はすなわち耐高温材料, 高融点材料を意味する。類似の スピント型構造の電子源において, エミッタ材料を変え たときの雑音電力を測ると, 融点の高いものほど雑音電 カが少ない。

さらに, 不活性な材料ほど表面に杂隹音の原因となるガ スの吸着が少ないので, 安定なエミッタが得られる。不 活性な材料としては, 炭素系材料が代表的であるが, こ の理由もあって, ダイヤモンド膜, DLC 膜, カーボン ナノチューブなどがェミッタ材料として好んで用いられ ている。

5.3 エミッタ材料の選択 (低仕事関数材料) による 電流安定化

仕事関数の低い材料ほど雑音電力が少なくなる。窒化 物も不活性な材料であるが, 弚の中でも, $\mathrm{NbN}$ や $\mathrm{rN}$ は室素組成によって仕事関数が変化する。Fig. 12 は, イオンビームアシスト蒸着法で作製した $\mathrm{NbN}$ 膜の窒素 組成に対する接触電位差 (仕事関数と相対関係がある) の関係を示す ${ }^{7)}$ 。接触電位差が低いほど仕事関数も低い。 Fig. 13 は， NbN を用いたフィールドエミッタの放出電 流の雑音電力を示す。仕事関数が低いほど雑音電力が少 ないことがわかる。このように，仕事関数の低い材料を エミッタに用いるのも 1 つの選択肢である。

仕事関数が低いという意味では, 負の電子親和力表面 をもつ材料, ダイヤモンドや $\mathrm{AlN}^{8)}$ もエミッタ材料とし て非常に期待できる材料である。

5.4 多数のエミッタ動作の平均による電流の安定化 1 個のエミッタを動作している場合の雑音よりも，多 数個 ( $N$ 個) のエミッタを動作しているときには, 統計 


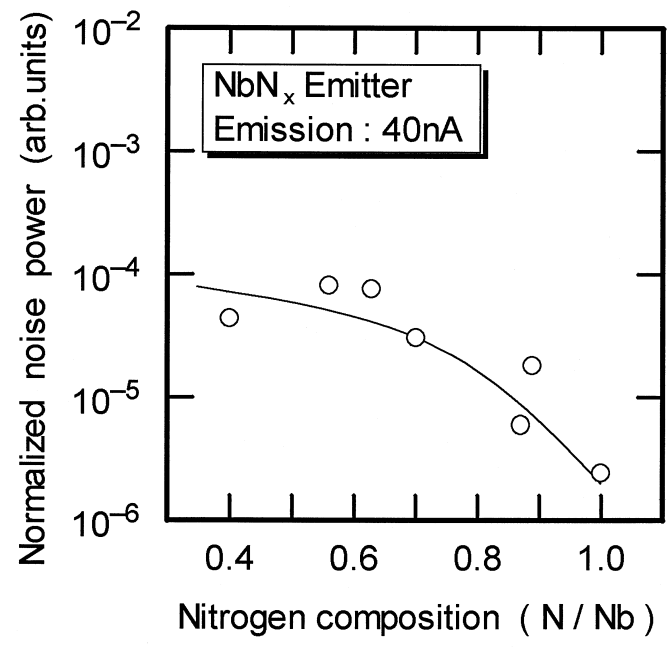

Fig. 13 Normalized noise power as a function of nitrogen composition of $\mathrm{NbN}$ film prepared by ion beam assisted deposition.

的な平均がなされ，雑音は $1 / \sqrt{N}$ になる。したがって， エミッタアレイが全て動作し同程度の平均電流を放出し ているものを用いると仮定すれば，この方法により雑音 の少ないエミッタを実現できることになる。

しかし，エミッタアレイの中で十分な電流を放出して いるものの数は少ないので, 多数のエミッタを動作させ る利点は, 確実にエミッタを動作させることにある。
6.おわりに

微小フィールドエミッタアレイは, ヒータ不要で通常 の真空度で動作できるだけでなく，超高電流密度あるい は平面状の構造が実現できるため，今後応用において多 くの可能性を秘めた電子源である。実現に向けての最大 の課題は個々のエミッタの安定性であるが，弚の解決の 糸口としてェミッタの材料選択が鍵となるかも知れな い。

\section{文献}

1) C.A. Spindt: J. Appl. Phys. 39, 3504 (1968)

2) 村上裕彦: 学振 158 委員会第 29 回研究会資料 (1999) p. 20.

3) J.M. Kim : 学振 158 委員会第 29 回研究会資料 (1999) p. 9.

4) R.K. Parker, K.L. Jensen and R.H. Abrams: Technical Digest of 10th Int. Vacuum Microelectronics Conference (1997) p. 92.

5) K. Konuma, Y. Okada, A. Okamoto, Y. Tomihari and S. Miyano: Proc. 6th Int. Display Workshops (1999) p. 903.

6) S. Kanemaru, K. Honda, T. Kobayashi, K. Ehara and J. Itoh: Proc. 4th Int. Display Workshops (1997) p. 735.

7) Y. Gotoh, H. Tsuji and J. Ishikawa: Proc. 7th Int. Display Workshops (2000) p. 991.

8) M. Kasu and N. Kobayashi: Proc. 7th Int. Display Workshops (2000) p. 987. 